\title{
Seedling mortality in quercus leucotrichophora A. Camus, pinus roxburghii D. Don and shorea robusta Gaertn forest of Kumaun Himalaya, India
}

\author{
Sanjay Kumar, Lalit M. Tewari \\ Department of Botany, D.S.B. Campus, Kumaun University, Nainital-263002
}

Email address:

sanjay14_kumar@yahoo.in(S. Kumar)

To cite this article:

Sanjay Kumar, Lalit M. Tewari. Seedling Mortality in Quercus Leucotrichophora A. Camus, Pinus Roxburghii D. Don and Shorea Robusta Gaertn Forest of Kumaun Himalaya, India. International Journal of Environmental Monitoring and Analysis. Vol. 1, No. 3, 2013, pp.91-94. doi: 10.11648/j.ijema.20130103.13

\begin{abstract}
The studies on plant demography hold a considerable significance in plant ecology. Natural regeneration of different plant species through seeds depend primarily upon seed production, germination capacity of seeds and successful establishment of seedling. Successful regeneration of tree species might be considered to be a function of three major components; ability to initiate new seedlings, ability of seedlings and saplings to survive and ability of seedlings and saplings to grow. Several environmental stresses are known to affect the seedling growth but water stress isbelieved to be a major one. The canopy density and soil conditions also affect the growth of seedling. This study comprises three study sites located at $29^{\circ} 22^{\prime} \mathrm{N}$ latitudes and $79^{\circ} 29^{\prime}$ E longitudes along an elevation transect of $350-2500$ m in Kumaun Himalaya. This region has certain characteristic climatic features. Though it falls under sub-tropical latitude, the abrupt rise in mountains creates a temperature comparable to that of a temperate climate. The seedling dynamics were studied at sal forest, banj oak forest and chir pine forest. For the computation of seedling mortalityand other characteristics, $2 \times 2 \mathrm{~m}$ permanent quadrats wereestablished in sal, chir-pine and banj oak forest. A total of 12 quadrats were placed in the stand ( 3 quadrats in each site). To record the mortality of the seedlings, all the seedlings of the year 2008 present in twelve quadrats in each forest were tagged. Their mortality was observed monthly from January 2009 - December 2009. Results show that mortality was very low $(20 \%)$ at sal forest as compared to banj oak forest $(25 \%)$ and chir pine forest (35\%). The chir pine forest was heavily affected by human disturbance. So the seedling population was more affected if compared to two other sites. Since the biotic stress was negligible there was very little mortality during the study period in banj oak and sal forest suggesting that if biotic stress and natural disturbance is minimum, the rapid regeneration of Q. leucotrichophora and $S$. robusta would be possible.Current study provides information on the seedling dynamics in three forests types in the Kumaun Himalaya. Results show seedling mortality was very low (20\%) at sal forest if compared to banj oak forest (25\%) and chir pine forest (35\%) so the rapid regeneration of $Q$. leucotrichophora and $S$. robusta would be possible.
\end{abstract}

Keywords: Seedling Mortality, Banj Oak Forest, Chir Pine Forest, Sal Forest, Kumaun Himalaya

\section{Introduction}

Regeneration of forest trees generally depends upon the ability of trees to provide seeds, ability of seeds to germinate and ability of seedlings to grow and survive in the under canopy environment where soil moisture and light may often be limiting (Good and Good 1972). The primary requirement for successful regeneration for all tree species in that viable seeds should reach the ground in adequate number (Zasada Iet al., 1978). The effect of environment on seed germination is very complex because of interaction of external and internal factors which modify the rate and magnitude of germination (Rao, 1984). However, among the various environmental factor water, temperature and light are of paramount importance which influence the seed germination (Downs 1964, Mc Lemore 1968, Toole and Borthwick 1968, Rollin 1971).

In regard to the seedling growth of Indian oaks Troup (1921) has made pioneering work. The regeneration of oaks in Kumaun Himalaya is reported to be unsatisfactory mainly because of biotic disturbance (Singh and Singh 1985). Upreti (1982) has reported that oaks in Kumaun Himalaya 
regenerate well when disturbance is limited. Others who have recorded the regeneration status of central Himalayan oaks are Saxena (1979) and Rao (1984). Singh et al., (1985) have emphasized on the role of "coppicing" a type of vegetative propagation in oak regeneration.

\section{Description of the Study Area}

\subsection{Study Site and Vegetation}

This study comprises three study sites located between 29o 22' $\mathrm{N}$ latitudes and 79o 29' E longitudes along an elevation transect of $350-2500 \mathrm{~m}$ in Kumaun Himalaya (Fig. 1). The degree of evergreeness increases with elevation (Singh and Singh 1987). In general, from lower to higher elevations dominantion of following forest prevailed: Sal (Shorea robusta) forests below $1000 \mathrm{~m}$; Chir pine (Pinus roxburghii) forest between $1000 \mathrm{~m}-100 \mathrm{~m}$; Banj oak (Quercus leucotrichophora) forests between $1600-2200 \mathrm{~m}$.

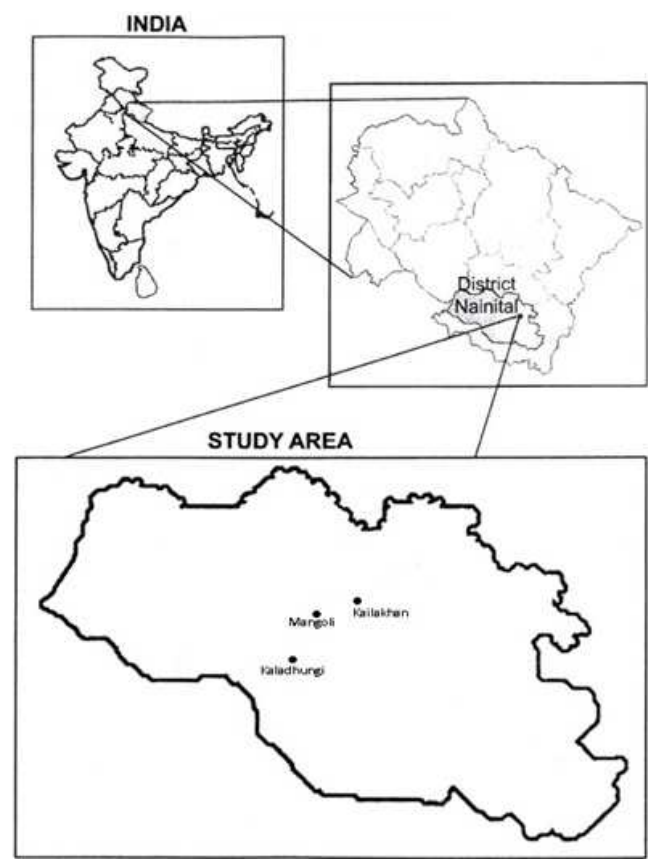

Fig 1. Location map of the study area

\section{Materialsand Methods}

\subsection{Climate of the Study Area}

This region has certain characteristic climatic features. Though it falls under sub-tropical latitude, the abrupt rise in mountains creates a temperature comparable to that of a temperate climate. Data obtained from the State Observatory at Nainital for the study years (2008-09) indicate that within the elevation transect of $1000-2500 \mathrm{~m}$ the mean monthly maximum temperatures range from $14^{\circ} \mathrm{C}$ in November to $30^{\circ} \mathrm{C}$ in May; mean monthly minimum temperatures from $-2^{\circ} \mathrm{C}$ in January to $16^{\circ} \mathrm{C}$ in October and mean monthly rainfall ranges from $4 \mathrm{~mm}$ in December to $611 \mathrm{~mm}$ in August. The winters are severe and frosts are common from
December to February. Data obtained from the O/I Agromet Observatory, Pantnagar indicated that within the elevation transect of 400-1200 $\mathrm{m}$ the mean monthly maximum temperatures range from $20^{\circ} \mathrm{C}$ in January to $36^{\circ} \mathrm{C}$ in May; mean monthly minimum temperatures from $7^{\circ} \mathrm{C}$ in January to $26^{\circ} \mathrm{C}$ in July and mean monthly rainfall ranges from $1 \mathrm{~mm}$ in January to $148 \mathrm{~mm}$ in August. Also, temperatures increase with decreasing elevation (Fig. 2).

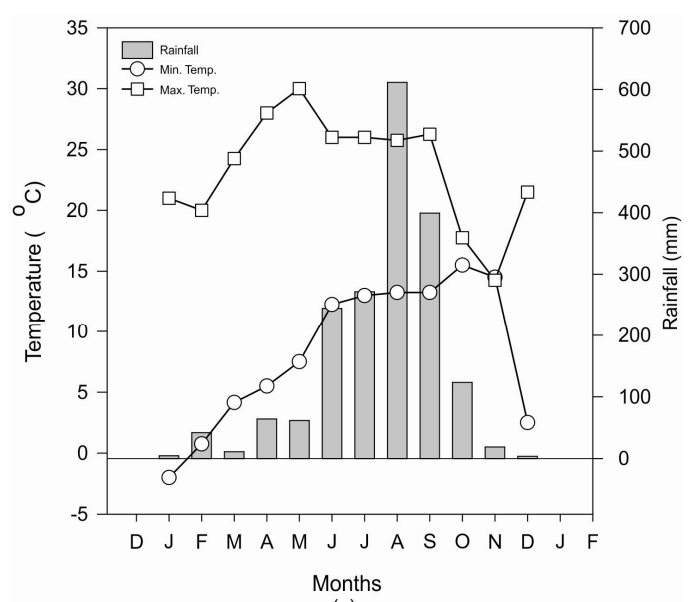

(a)

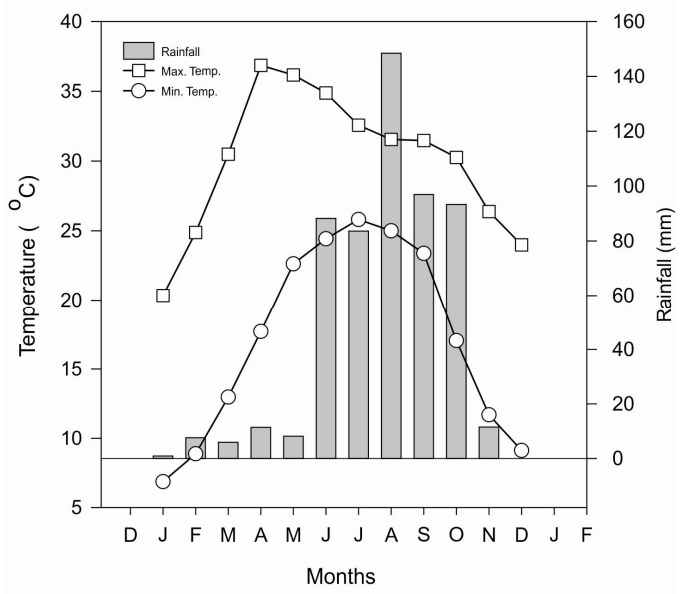

(b)

Fig 2. Meteorological data for high altitude (a) and lower altitude (b)

\subsection{Soil}

The Soil was sandy loam, with sand percentage being highest at 400-900 m elevation and lowest at 1600-1700 m elevation. An increasing trend with elevation was found for soil organic matter content $(r=0.67, P<0.05)$, clay $(r=0.89$, $\mathrm{P}<0.01)$ and water holding capacity $(\mathrm{r}=0.84, \mathrm{P}<0.01)$. Soil $\mathrm{pH}$ ranging between 5.1 to 7.9. Among the soil nutrient the available Nitrogen concentration increases with increasing elevation $(\mathrm{r}=0.81, \mathrm{P}<0.05)$. Available Phosphorus was maximum in the soil of high elevation sites, occupied by forest of oaks (Quercus spp.) and least in low elevation site occupied by Sal (Shorea robusta) forest. The soil of oak forests was markedly richer in available Potassium than those of other forest types such as Sal forest and Chir pine forest (Pinus roxburghii) (Kumar, 2011). 


\section{Methods}

The seedling dynamics were studied at sal forest, banj oak forest and chir pine forest. For the computation of seedling mortalityand other characteristics, $2 \times 2 \mathrm{~m}$ permanent quadrats was established in sal, chir-pine and banj oak forest. A total of 12 quadrats were placed in the stand ( 3 quadrats in each site). To record the mortality of the seedlings, all the seedlings of the year 2008 present in twelve quadrats in each forest were tagged. Their mortality was observed monthly from January 2009 - December 2009. Attempts were made to ascertain the causes of the seedling mortality (Joshi, 1990).

\section{Results}

In January 2009 the total number of seedling present in 12 , $2 \times 2 \mathrm{~m}$ quadrats at each site was 90 at banj oak forest, 60 at chir pine forest, 72 at sal forest. At banj oak forest the total number of seedling decreased to 78 in month of March, 66 in April, 52 in May-June, 42 in July and after July all the seedling remained constant throughout the study period. At chir pine forest the number of seedling decreased to 52 in month of February, 40 in March, 24 in May, 14 in June and after June all the seedling remained constant throughout the study period. At sal forest the number of seedling decreased to 66 in month of March, 54 in April-May, 24 in June and after June all the seedling remained constant throughout the study period.

\subsection{Banj Oak Forest}

At banj oak forest the average number of seedling was 7.5 $\mathrm{m}^{-2}$ in January and February (i.e. 75,000 seedling ha ${ }^{-1}$ ) while in March it was decreased to 6.5 seedlings $\mathrm{m}^{-2}$. Thus $13.33 \%$ seedling mortality occurred in March. In April the seedling was decreased to $5.5 \mathrm{~m}^{-2}$, thus $26.66 \%$ seedling mortality occurred in April. In May and June the number of seedling was decreased to $4.3 \mathrm{~m}^{-2}$ thus $42.66 \%$ seedling mortality occurred. In July the number of seedling was decreased to 3.5 seedling $\mathrm{m}^{-2}$, thus the seedling mortality was $53.33 \%$ in month of July. After July no seedling mortally occurred (Fig. $3)$.

\subsection{Chir Pine Forest}

At chir pine forest the average number of seedling was 5.0 $\mathrm{m}^{-2}$ in January and February (i.e. 50,000 seedling ha ${ }^{-1}$ ). In month of March it was decreased to 4.3 seedling $\mathrm{m}^{-2}$, thus $14 \%$ seedling mortality occurred. In April the number of seedling was reduced to 3.3 seedling $\mathrm{m}^{-2}$, thus $34 \%$ seedling mortality occurred. In June seedling was reduced to 2.0 seedling $\mathrm{m}^{-2}$ thus $60 \%$ mortality occurred. In June the seeding number was reduced to $1.3 \mathrm{~m}^{-2}$ thus $74 \%$ seedling mortality occurred and remained constant through the study period (Fig. 3).
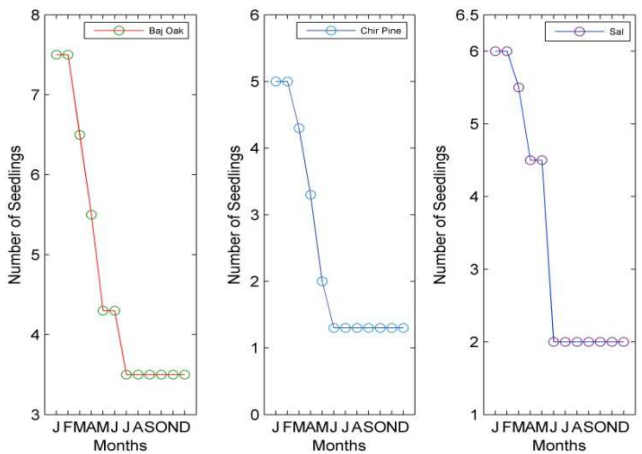

Fig 3. Decline in average number of seedlings $m^{-2}$ during the study in banj oak, chir pine and sal forest

\subsection{Sal Forest}

At sal forest the average number of seeding was $6.0 \mathrm{~m}^{-2}$ in January and February (i.e. 60,000 seedling ha ${ }^{-1}$ ). In March the seedling number was decreased to 5.5 seedling $\mathrm{m}^{-2}$, thus $8.33 \%$ seedling mortality occurred. In April the number of seedling was reduced to 4.5 seedling $\mathrm{m}^{-2}$, thus $25 \%$ seedling mortality occurred. In June the seedling was reduced to 2.0 seedling $\mathrm{m}^{-2}$, thus about $66.66 \%$ seedling mortality occurred. After June no seedling morality occurred (Fig. 3).

Table 1. Average number of seedlings per $m^{2}$ and their mortality in banj oak forest during the study period.

\begin{tabular}{cccc}
\hline Month & Average & Mortality & $\begin{array}{c}\text { Cumulative } \\
\text { mortality (\%) }\end{array}$ \\
\hline January & 7.5000 & - & - \\
February & 7.5000 & 1 & 25 \\
March & 6.5000 & 2 & 50 \\
April & 5.5000 & 3.2 & 80 \\
May & 4.3000 & 3.2 & 80 \\
June & 4.3000 & 4 & 100 \\
July & 3.5000 & - & - \\
August & 3.5000 & - & - \\
September & 3.5000 & - & - \\
October & 3.5000 & - & - \\
November & 3.5000 & - & - \\
December & 3.5000 & - & \\
\hline
\end{tabular}

Table 2. Average number of seedlings per $\mathrm{m}^{2}$ and their mortality in chir pine forest during the study period.

\begin{tabular}{cccc}
\hline Month & Average & Mortality & $\begin{array}{c}\text { Cumulative } \\
\text { mortality (\%) }\end{array}$ \\
\hline January & 5 & - & - \\
February & 5 & 0.7 & 18.92 \\
March & 4.3 & 1.7 & 45.95 \\
April & 3.3 & 3 & 81.08 \\
May & 2 & 3.7 & 100 \\
June & 1.3 & - & - \\
July & 1.3 & - & - \\
August & 1.3 & - & - \\
September & 1.3 & - & - \\
\hline
\end{tabular}


Table 3. Average number of seedlings per $m 2$ and their mortality in sal forest during the study period.

\begin{tabular}{cccc}
\hline Month & Average & Mortality & $\begin{array}{c}\text { Cumulative } \\
\text { mortality (\%) }\end{array}$ \\
\hline January & 6 & - & - \\
February & 6 & 0.5 & 12.5 \\
March & 5.5 & 1.5 & 37.5 \\
April & 4.5 & 1.5 & 37.5 \\
May & 4.5 & 4 & 100 \\
June & 2 & - & - \\
July & 2 & - & - \\
August & 2 & - & - \\
September & 2 & - & \\
\hline
\end{tabular}

The extent of seedling mortality shows a sharp rise in mortality from February to April in banj oak and chir pine forest and April to May in sal forest. In banj oak forest $100 \%$ cumulative mortality occurred in month of June (Table 1) compared to chir pine and sal forest where $100 \%$ cumulative mortality occurred in month of May (Table 2 and 3).

\section{Conclusion}

Seedling germination and seedling establishment are the very critical phases in the life cycle of a species (Ramakrishnan 1972, Harper and White 1974). The duration and simple conditions and the rate at which the seed is able to respond to these are major factor which determine the germination and establishment in the field condition (Harper, 1965). The regeneration potential of the vegetation largely depends upon the size of seed crop, seedling establishment and their survival. The average number of seedling surviving until December 2009 was $3.5 \mathrm{~m}^{-2}$ for banj oak forest, $1.3 \mathrm{~m}^{-2}$ for chir pine forest and $2.0 \mathrm{~m}^{-2}$ for sal forest. However, the value was lower at chir pine forest $\left(1.3 \mathrm{~m}^{-2}\right)$ and higher at banj oak forest $\left(3.5 \mathrm{~m}^{-2}\right)$.

In the present study seedling mortality was very low (20\%) at sal forest compared to banj oak forest $(25 \%)$ and chir pine forest $(35 \%)$. The chir pine was forest was heavily affected by human disturbance. So the seedling population was more affected compared to two other sites. Since the biotic stress was negligible there was very little mortality during the study period in banj oak and sal forest suggesting that if biotic stress and natural disturbance is minimum, the rapid regeneration of $Q$. leucotrichophora and $S$. robusta would be possible.

\section{References}

[1] Downs, R. J. (1964) Photocontrol of germination of seeds of the Bromeliaceae. Phyton. 21: 1-6.

[2] Good, N. F. \& Good, R. E. (1972) Publication dynamics of trees seedlings and saplings in the mature eastern hardwood forest. Bull. Torrey Bot. Club 39: 172-178.

[3] Harper, J. L. \& White, J. (1974) The demography of plants. Annu. Puri. Ecol. Syst. 5: 419-463.

[4] Harper, J. L. (1965) Establishment, aggressioned, Co-habitation in weedy species, p 243-268. In H. G. Baker and G. L. Stebbins (eds.). The genetics of colonizing species. Academic Press. Inc. New York.

[5] Joshi, B. (1990) Population dynamics and growth behavior of Quercus floribunda Lindl. seedlings in Kumaun Himalaya. Ph.D. Thesis, Kumaun University, Nainital, India.

[6] Kumar, S. (2011) Studies on phenology and seedling dynamics of major tree and shrub species along an altitudinal gradient in Kumaun Himalaya. Ph.D Thesis, Kumaun University, Nainital,.

[7] Mc Lemore, B. F. (1968) The influence of light on germination of long leaf pine seed. Dissertation Abstr. 2: 181-236.

[8] Ramakrishnan, P. S. (1972) Individual adaptation and its significance in population dynamics. In biology of Land Plants (344-355) ed. V Puri eV al (Meerut Sarita Prakashan).

[9] Rao, P. B. (1984) Regeneration of some trees of Western Kumaun Himalaaya. Ph.D. Thesis, Kumaun University, Nainital, India.

[10] Rollin, P. (1971) Phytochrome control of seed germination, Phytochrome (ed. By R. Mitrakos and W. shrophashire, Jr.). 230-349.

[11] Saxena, A. K. (1979) Ecology of vegetation complex of North-Western catchment of river Gola. Ph.D. Thesis, Kumaun University, Nainital.

[12] Singh, J. S. \& Singh, S. P. (1987) Forest vegetation of the Himalaya. The Botanical Review, 53(1): 80-192.

[13] Singh, S. P. \& Singh, J. S. (1985) Man and environment: The Central Himalayan Case. Biol. Mem. 11(1): 47-59.

[14] Singh, S. P., Ralhan, P. K. \& Tewari, J. C. (1985) Stability of Himalayan Climax oak forests in view of Resilience Hypothesis Env. Cons. pp. 73-75.

[15] Toole, V. K. \& Borthwick, M. A. (1968) The photo-reaction controlling seed germination in Eragrostis Currula. Plant Cell Phytol. 9: 125-136.

[16] Troup, R. S. (1921) The silviculture of Indian trees. Vol. I-III. Oxford at the Glarendon Press. 1195p.

[17] Upreti, N. (1982) A study on phytosociology and state of regeneration of oak forests at Naini Tal. Ph.D. Thesis, Kumaun University, Naini Tal. 481p. 